\title{
Tudásmenedzsment a közigazgatási munkában
}

A tanulmány rövid elméleti bevezetés után áttekinti a tudásmenedzsment szerepét, lehetőségeit és feladatait az. elektronikus kormányzati munkában. A nyitott, átlátható és a jelenleginél hatékonyabb, produktívabb közszféra megteremtését célzó közigazgatási reformtörekvések a tudásközpontú gondolkodás, tervezés és működés gyakorlatának megvalósítását sürgetik. A szerző ismerteti a kormányzati front-office és back-office folyamatokat és felvázolja a tudásmenedzsment lehetőségeit, amelyek az információs társadalomban felhasználhatók a demokratizálódás és az állampolgár-formálás érdekében.

\section{Szerzői információ:}

Gé ró Ka t a li n

Debrecenben, a Kossuth Lajos Tudományegyetem Természettudományi Karán szerzett angol nyelvtanári és informatikus-könyvtáros diplomát. Az egyetem elvégzése óta az információgazdálkodás és rendszerfejlesztés területén dolgozik, és 1997 óta a tudásmenedzsment fốként elméleti kérdéseivel foglalkozik. A vállalati szektorban és a közszférában (közgyüjtemények, illetve közigazgatás) szerzett munkatapasztalatok alapozták meg a kormányzati tudásmenedzsment lehetôségeinek kutatását. 2003 januárja óta részt vesz a Miniszterelnöki Hivatal Elektronikus Kormányzat Központjának megbízásából folyó „e-Kormányzat első kézből”" projekt munkájában az Információs Társadalom és Trendkutató Központ keretein belül. 
Gé ró $\mathrm{K}$ a $\mathrm{t}$ a $\mathbf{l}$ i $\mathrm{n}$

\section{Tudásmenedzsment a közigazgatási} munkában

A közigazgatási rendszer ${ }^{1}$ és ezen belül a kormányzati apparátus hagyományosan kisebb-nagyobb lemaradással szokta magáévá tenni az újabb és újabb üzletfejlesztési és technikai vívmányokat. Igaz ez a tudásmenedzsmentre is, ami a privát szférához képest lényegesen lassúbb tempóban ugyan, de kezdi elfoglalni biztos helyét a közigazgatás és a kormányzati munka világában is.

Az utóbbi évtizedekben a fejlett országokban teret nyerố átfogó közigazgatási reformtörekvések (New Public Management) olyan új vonásokat hoztak a közszférába, amelyek lehetôvé teszik, illetve sürgetik a tudásmenedzsment terén a privát szektorban szerzett tapasztalatok (szemlélet, modellek, eljárások) adaptációját (Közig. Int., 2002:40). A nagy nemzetközi szervezetek többsége a tudásmenedzsment koordinálásával foglalkozó részlegek ${ }^{2}$ létrehozásával, pályázatok kiírásával, különféle programok finanszírozásával igyekszik egyre inkább szorgalmazni és támogatni a tudásmenedzsment kutatását, fejlesztését és meghonosítását a közszférában.

Az e-kormányzat eszközrendszerével is támogatott közigazgatási reform célja ma már a nyitott és átlátható, a jelenleginél hatékonyabb és eredményesebb, ha úgy tetszik, produktív közszféra megteremtése, amely mindenki számára egyenlôen elérhetô, állampolgár-barát, személyre szabott szolgáltatásokat nyújt. Az intézményrendszer megreformálása és az elektronikus kormányzat eszközrendszerének kiépítése átfogó, néhol merốben új szervezeti, kulturális és technológia kihívások elé állítja a közigazgatást. A közigazgatási munka szerkezeti, szervezeti és kulturális változásainak megvalósításához nélkülözhetetlen technológiai fejlesztés komplex rendszere olyan tudásközpontú szervezeti mûködést igényel, amit a hagyományos struktúra és a hagyományos munkafolyamatok már nem tudnak biztosítani. A közigazgatási rendszerek reformtervezeteiben olyan követelményekkel találkozunk, mint például az állami szféra hatékonyságának, múködési színvonalának, illetve az általa nyújtott szolgáltatások minôségének növelése. A tudásközpontú gondolkodás, tervezés és múködés

\footnotetext{
${ }^{1}$ A napi szóhasználatban jelentkezô fogalmi ellentmondások miatt fontosnak tartjuk a „közigazgatás” kifejezés jelentésének pontosítását. A közigazgatás az állami feladatokat végrehajtó, szervezô és igazgató tevékenység, az államigazgatási és az önkormányzati igazgatási alrendszerek összessége.

${ }^{2}$ Az ENSZ-ben a Közigazgatási és Fejlesztési Osztály (Division for Public Administration and Development Management) gondozza a tudásmenedzsmenttel és az e-kormányzattal kapcsolatos feladatokat (tudásmenedzsment és tudáslétrehozás, e-kormányzat, IKT eszközök használata a részvételen alapuló demokráciában, tudásfejlesztés és innováció a gazdasági fejlôdés érdekében, az IKT eszközök szerepe az önkormányzatok fejlesztésében). Az $O E C D$-ben a közigazgatással és térségfejlesztéssel foglalkozó igazgatóság (Directorate for Public Governance and Territorial Development) koordinálja a tudásmenedzsmenttel és az ekormányzattal összefüggő feladatokat. Az Európai Unión belül a Knowledge Board program igyekszik összefogni a tudásmenedzsment fejlesztésére irányuló európai non-profit kezdeményezéseket és a szakmai közösséget (http://www.knowledgeboard.com/cgi-bin/item.cgi?id=69381). A tudásmenedzsment az információs társadalom megvalósítását célzó programnak is kiemelt területe.
} 
gyakorlatának kialakulása sokféle módon elősegíthetô. Felhasználható erre a célra többek között a szervezés és vezetés terén bevált technológiák és módszerek átvétele a vállalati szektortól, továbbá a folyamatközpontú közigazgatás-szervezés, a szolgáltatók versenyeztetése, az egyes igazgatási és szolgáltatási tevékenységek kiszervezése (outsourcing), a hagyományosan központosított szervezeti felépítés és döntéshozatali gyakorlat visszaszorítása és az állampolgárok ügyfélként való kezelése. Az állampolgároknak nyújtott szolgáltatások tartalmi menedzselése, valamint az egykapus e-kormányzati szolgáltatások kialakítása hatékony adat-, információ- és tudásmegosztást, illetve együttmúködést igényel a különböző intézmények és szereplốk között. A közigazgatási munka racionalizálását és múködési költségeinek csökkentését célul kitûzô reformok sürgetik az intézmények tevékenységi körében meglevố átfedésekből származó redundancia kiszúrését, illetve kiküszöbölését. A fenti célok megvalósításához nélkülözhetetlen egységes, vagy legalábbis kompatibilis technológiai platform kialakításához központi koordinációra van szükség. Mindezeknek a feladatoknak a központosított ellátása - a közigazgatási szolgáltatások és a kormányzati munka hatékonyságának növelésén túl - komoly költségmegtakarítás lehetőségét is magában hordozza. A tudásmenedzsment szemléleténél és eszközrendszerénél fogva katalizátorszerepet tölthet be ezekben a reformokban. Fontosnak tartjuk hangsúlyozni, hogy az átfogó közigazgatási reform végrehajtásakor önmagában sem a tudásmenedzsment, sem az e-kormányzat megteremtésére irányuló törekvés nem lehet cél, hanem csak hatékony eszköz.

\section{A tudásmenedzsment elméleti alapjai}

A tudásmenedzsment tárgyalásánál nem kerülhetô meg az adat, az információ és a tudás kategóriái között fennálló hierarchikus kapcsolatok meghatározása. Az adat „eseményekkel kapcsolatos, elvont, objektív tények összessége” (Davenport-Prusak, 2001:18). Amennyiben az adatot értelmezzük, jelentéssel ruházzuk fel, illetve az valamilyen kommunikációs folyamat részévé válik, információról beszélhetünk. A tudás fogalmának meghatározása már sokkal bonyolultabb feladat. Más és más szempontból közelít hozzá az elvont, filozófiai tárgyalásmód, ami a tudás mibenlétét és természetét kutatja; a pszichológia, ami a tudásnak az emberi viselkedésben játszott szerepével foglalkozik; a szociológia, ami a tudás társadalmi szerepét vizsgálja, és a legújabb megközelítési mód, az üzleti szemlélet, ami a tudás jelentőségét az egyén és a szervezet teljesítményének és hatékonyságának növelésében látja. A különféle megközelítések megegyeznek abban, hogy az információ tudássá történó átalakítása az emberi elme transzformációs tevékenységének eredménye. Davenport és Prusak (Davenport-Prusak, 2001:21) meghatározása ${ }^{3}$ szerint a tudás keretbe fogalt tapasztalatok, értékek és egymással összekapcsolt információk heterogén, folytonosan változó együttese, ami megfelelő környezetet és keretet biztosít új tapasztalatok és információk értékeléséhez és elsajátításához. Ezek a folyamatok elsősorban maguknak a tudással rendelkező személyeknek az elméjében mennek végbe. Az egyes szervezetekben a

${ }^{3}$ E tanulmány keretei között nem célunk a vita részletes ismertetése, így a tudásmenedzsmenttel foglalkozó szakirodalom egyik széles körben elfogadott definícióját ismertetjük. 
tudás nem csupán dokumentumokban és adattárakban található meg, hanem gyakorta beágyazódik a szervezet mindennapi munkafolyamataiba, gyakorlati tevékenységeibe és az azokat meghatározó szabályokba.

A tudás - a kognitív tudományok megközelítése szerint - megjelenési formáját tekintve lehet explicit (artikulált, kodifikált) vagy tacit (hallgatólagos, rejtett). Nonaka és Takeuchi (Nonaka-Takeuchi, 1995) - Polányi Mihály (Polányi, 1994) tudásfelosztási rendszerét alapul véve - a valamely közösségen belül explicit, illetve tacit formában megjelenő tudás keletkezésének lehetséges módjait az alábbiakban határozták meg:

1.táblázat

Nonaka-mátrix (A tudás keletkezésének négy módja)

\begin{tabular}{c|c|c|} 
& Tacit tudás $(\mathrm{T})$ & Explicit tudás $(\mathrm{E})$ \\
\hline Tacit tudás $(\mathrm{T})$ & Szocializáció & Externalizáció \\
\hline Explicit tudás $(\mathrm{E})$ & Internalizáció & Kombináció \\
\hline
\end{tabular}

T-T: amikor egy személy közvetlen módon megosztja ismereteit egy másik személlyel, azaz a közvetlen emberi kommunikáció;

E-E: amikor valaki a létező, dokumentált tudásból új, dokumentált ismeretet hoz létre;

T-E: amikor valaki rögzíti, ezáltal átalakítja személyes tudását explicit, dokumentált tudássá;

E-E: rögzített, dokumentált ismeretek felhasználása új összefüggések felismerése vagy ismeretek létrehozása céljából.

A tudásmenedzsment számára a nagy kihívást leginkább a két utolsó dimenzió jelenti, vagyis az, hogy miként ragadjuk meg és hogyan tegyük közkinccsé az emberi elmékben elraktározott tudást, szakértelmet és tapasztalatokat, és miként hasznosíthatjuk a felhalmozott, már dokumentált ismereteket a szervezet alapvetố tevékenységében és folyamatos fejlődésében.

A tudásmenedzsment fogalmán belül a tudást felfoghatjuk tárgyként (object) és folyamatként (process) (Sveiby, 1996-2001). A fớként az információtechnológiára orientált megközelítés szerint a tudás olyan aktív információ, amivel valaki értékteremtés céljából valamilyen tevékenységet végez, illetve amit egy információs rendszerben kezelni lehet. Az inkább emberre-orientált megközelítés a tudást folyamatként értelmezi, ahol a tudás folyamatosan változó, dinamikus készségek (pl. szakmai ismeretek) komplex tára. Malhotra (Malhotra, 1998) - egyesítve a technológiai és a humán szempontú megközelítéseket - a tudásmenedzsmentet két tényezố, nevezetesen az információs technológiák adat- és információfeldolgozó képessége, illetve a humán kreativitás és innovációs készség szinergikus kombinációjának tekinti.

Minden szervezet a külvilágból nyeri az általa használt információk nagyobb (explicit) részét, míg tacit tudása fóként alkalmazottainak elméjében raktározódik el, s ez utóbbit nehéz kézzelfogható módon kiaknázni. A feladat a munkafolyamatok oly módon történő kialakítása, hogy a szervezeti tudásépítésben a szervezet valamennyi tagja állandóan érintett legyen. A beszerzési, összegyújtési folyamat eredménye a nyers információ és tudásanyag, ami a következő fázisnak, a tudástermelés folyamatának az alapját képezi. Az összegyújtött nyersanyag emberek által végzett feldolgozása eredményezi az új ismeretek születését. Az így születố új ismeretek akkor kapnak 
értelmet a tudásmenedzsment szempontjából, ha szervesen beépülnek a szervezet tudásrendszerébe. A dokumentált és a tacit tudásból nyert tudáselemeket a hatékony alkalmazás és újrafelhasználás érdekében nem elegendő csupán továbbítani, hanem ahhoz, hogy ne kallódjanak el és eredményesen hozzájáruljanak a folyamatos szervezeti tanuláshoz (organizational learning), megfelelő útmutatókkal is el kell látni azokat, akikhez továbbítjuk őket. A tudásmenedzsment tehát nem igazán a tudás, hanem sokkalta inkább a tudásátadási folyamatok menedzselése. Ezt a nézetet vallja Sveiby (Sveiby, 2000) is, aki szerint a tudás önmagában nem „menedzselhetô”, csak a környezete.

Ha gyakorlati szempontból közelítjük meg a kérdést, a legszemléletesebb az American Productivity and Quality Center (APQC) minden tudományos megfogalmazást nélkülöző, végtelenül egyszerú, de célratörő megfogalmazása, miszerint a tudásmenedzsment a megfelelő információnak vagy tudásnak a megfelelố személyhez a megfelelő pillanatban és a megfelelô formában történố eljuttatása.

\section{Tudásmenedzsment a közigazgatásban}

Általános nézet a szakirodalomban és a köztudatban egyaránt, hogy a tudásmenedzsment alkalmazása gördülékenyebb és sikeresebb a privát szektorban, mint a nonprofit területeken, például a közigazgatásban. Anélkül, hogy ezt a megállapítást cáfolnánk, szeretnénk hangsúlyozni, hogy a tudásmenedzsment semmiképpen sem lehet idegen a közigazgatástól, hiszen valamennyi kormányzati és közigazgatási feladat igen közel áll a tudásmenedzsment gondolatvilágához és tevékenységi köréhez. A kormányzat és az adminisztratív közintézmények jellegükből és funkciójukból fakadóan fôként adat-, információ- és tudástárakkal foglalkoznak (feladatuk többek között az állampolgárokra vonatkozó társadalmi, üzleti, piaci, jogi és politikai jellegú adatok és információk gyưjjtése, feldolgozása és nyilvántartása, a jogalkotás és a szabályozás), illetve munkájuk eredményei is nagyobbrészt információ vagy tudás formájában kerülnek nyilvánosságra. Fontos még megjegyezni, hogy a közigazgatás ezeknek az adatoknak és információknak nem csupán felhasználója, hanem tulajdonosa is. A kormányzat legnagyobb tőkéje a szervezeti keretein belül fellelhetô tudás, és ez a tudás mindinkább meghatározó szerephez jut a reformtörekvések következtében átalakuló kormányzati és közigazgatási munka felfogásában, miközben a tudásalapú múködés alapvető kihívássá és feladattá válik (Traunmüller-Wimmer, 2003a:11). A hagyományos közigazgatási folyamatok újragondolása és átszervezése a tudás elosztásának és megosztásának új formáit eredményezi. Az ügyfélközpontú, szolgáltató állam koncepciója azt a követelményt állítja fel, hogy az eddigi igazgatásközpontú szemléletet felváltsa a tartalomra orientált, szolgáltatásközpontú szemlélet, a tervezéstôl kezdve egészen a gyakorlati feladatok végrehajtásáig.

$\mathrm{Az}$ általános tudásmenedzsment fóbb feladatai: a szervezeti kereteken belül és kívül fellelhetô tudás menedzselése; a szervezeti memória (organizational memory) kialakítása; a tudástermelési ciklusok kidolgozása; a tudásbázis folyamatos használatához szükséges feltételek megteremtése; a szakértelem, a know-how és a képességek szervezett átadása; a tanuló szervezet létrehozása és a mindezeket támogató integrált technológiai eszközrendszer meghonosítása az intézményekben. Ezeket az általános 
célkitűzéseket a közigazgatás hatékonyságának növelésére, valamint az intézmények életképességének és versenyképességének folyamatos biztosítására vetítve Wiig (Wiig, 2000:3) az alábbi jövôképet határozta meg:

- hatékony közigazgatási szolgáltatások megvalósítása a társadalom valamennyi területén és rétegében;

- stabil, biztonságos, igazságos és szabályozott társadalom kialakítása, melyben az állampolgárok és a közigazgatási intézmények munkatársai egymással párbeszédre és együttmúködésre képes politikai erôkké válnak;

- a kereskedelmi és a szellemi tôke folyamatos építésével, fenntartásával és kiaknázásával támogatott jóléti társadalom kiépítése;

- nemzetközileg versenyképes állam megteremtése, a tudásorientált lakosság és a tudásalapú intézményrendszer segítségével.

A fenti célokat az alábbi - egymástól elkülönülő, mégis szorosan összefüggő cselekvési területeken kell megvalósítani:

- az összkormányzati együttmúködés hatékonyságát javító szabályozási környezet fejlesztése és az elektronikus kormányzat magvalósítása érdekében létrehozott, az üzleti szférát és a lakosságot megcélozó szolgáltatások (front-office folyamatok) kidolgozása és támogatása;

- a kormányzati és államigazgatási intézmények belsố (back-office) munkafolyamatainak átalakítása az olcsóbb és hatékonyabb múködés érdekében;

- a demokrácia bővítése a tudásmegosztási folyamatok révén, a civil és az üzleti szféra, valamint a lakosság bevonásával.

\section{Kormányzati szinten központilag koordinált feladatok}

Harman és Brelade (Harman-Bredale, 2001:18) nemesen egyszerú megfogalmazása szerint a kormányzatnak az a szerepe a tudásmenedzsmentben, hogy eljárjon minden olyan esetben, amikor az egyén és az egyes szervezetek már tehetetlenek, vagyis a törvényhozás, a szabályozás és a nagyobb volumenú beruházások esetében. A központi koordináció legfontosabb feladata az, hogy folyamatosan biztosítsa a támogató légkört és a megfelelố eszközrendszert, kidolgozza a rövid-és hosszú távú terveket, és általános elvi keretet alakítson ki a kitűzött célok eléréséhez szükséges együttmúködéshez. A tudásmenedzsment terén jelentkezô központi feladatok ellátására célszerú felállítani egy irányító, koordinációs és orientációs feladatkörrel rendelkező szervezetet. Ez a központi fenntartású koordináló szervezet hivatott a közigazgatás szereplő́i által a tudásmenedzsment megvalósításában követett politika és gyakorlat folyamatos elméleti és gyakorlati tá mogatására, ehhez irányelvek megfogalmazására, valamint az együttmúködést, a kompatibilitást, az adatcserét és a tudásmegosztást lehetôvé tevő architektúrák és szabványok kidolgozására. Legfontosabb feladatai:

- a közigazgatási információs források és szolgáltatások feltérképezése;

- a kormányzati információs politika és az információhoz való hozzáférés rendszerének kidolgozása; 
- a közigazgatási dolgozók információs kultúrájának kialakításához szükséges képzési rendszer és követelményrendszer kidolgozása,

- a kormányzati és közigazgatási tudásbázis filozófiájának és szerkezetének elméleti megalapozása, majd e tudásbázis megvalósításának koordinálása,

- a közigazgatás jelenlegi technológiai hátterének áttekintése, majd az eredmények alapján a fejlesztések további irányainak meghatározása és koordinálása, ${ }^{4}$

- kapcsolattartás a hazai és nemzetközi közigazgatási szerveknek a tudásmenedzsmentért felelôs intézményeivel és részlegeivel.

A megvalósítandó feladatok komplex volta miatt elengedhetetlen tényezô a folyamatos monitoring és visszacsatolás, aminek eredményességéhez már kezdettôl fogva nagy hangsúlyt kell helyezni a mérhető és értékelhető outputok tervezésére.

Alapvető fontosságú, hogy minél hamarabb elkészüljön a kormányzat átfogó tudásmenedzsment-stratégiája, ${ }^{5}$ aminek a tudásmegosztásra való törekvés és az együttmúködési készség szellemében számba kell vennie a rendelkezésre álló erőforrásokat, a tervezett tudásmenedzsment-rendszer elvi és gyakorlati tényezőit, és a megvalósításhoz szükséges feladatokat és erôforrásokat.

Az államot és a közigazgatási rendszert felfoghatjuk hatalmas, osztott, tudás-intenzív szervezetként, amely tudásmunkásokat (tisztségviselőket és szakértôket) alkalmaz, alapvetốen tudásalapú tevékenységet végez, és komplex döntéshozatali, illetve cselekvési kötelezettségek terhelik. A közigazgatási munka multidiszciplináris és többdimenziós jellegư (az IKT eszközök és architektúrák, a kommunikációs és szolgáltatási csatornák, a folyamatok, a résztvevôk, valamint a tudástípusok tekintetében egyaránt). Traunmüller és Wimmer (Traunmüller-Wimmer, 2003a:135) hangsúlyozzák az elektronikus kormányzatban előforduló tudástípusok és tudáshordozók értelmezésének, valamint az ezek között fennálló összefüggések feltérképezésének fontosságát. Az állam valamennyi alapvetố tevékenysége (a törvényhozás és az igazságszolgáltatás múködtetése, a gazdaság fejlesztése, az állampolgári jogok és érdekek védelme, a környezetvédelem, a válságkezelés) információs inputtal és outputtal jellemezhetô, és különbözố tudásfolyamatokat foglal magában. Traunmüller és Wimmer (Traunmüller-Wimmer, 2003a:140-142) ezek elemzéséhez az alábbi három nézőpont alkalmazását javasolja:

\footnotetext{
${ }^{4}$ A közigazgatási tudásmenedzsment rendszer sikeres múködését alapozza meg egy biztonságos, szemléletét tekintve homogén kormányzati technológiai platform. Wiig (2000:9) a közigazgatási IT rendszer alábbi főbb elemeit sorolja fel:

- egységes elektronikus levelezô platform a közigazgatás teljes rendszerében;

- a csoportmunkát támogató eszközök(groupware);

- specifikus tudás- és adattárak;

- intranet valamennyi minisztérium és egyéb közintézmény részére;

- az információs írástudás kiterjesztése a köztisztviselốkre és közalkalmazottakra, majd a lakosság egészére.

${ }^{5}$ Traunmüller és Wimmer (2003b:2) figyelmeztetnek arra, hogy a két szektor közötti alapvetô eltérések miatt nem célszerú a privát szférából átvenni tudásmenedzsment stratégiákat, s ennek alátámasztásául a közigazgatás összetett és sokszínû célrendszerére, túlszabályozottságára, törvényi keretek által meghatározott szervezeti kereteire és kommunikációs folyamataira stb. hivatkoznak.
} 
- a már létezố adat-, információ- és tudástárak fizikai megvalósulása és a bennük tárolt információk (személyi adatok, gazdasági adatok, cégadatok, földrajzi adatok nyilvántartásai; jogi adatbázisok, törvénytárak; kontrolling és vezetési információk),

- a kormányzati alaptevékenységek (stratégiai és politikaformáló tevékenység, szabályozási és irányítási tevékenység, végrehajtó tevékenység),

- a közigazgatás saját tevékenységi körére vonatkozó tudástartalmak (pl. szabályozási tevékenység, állampolgári jogok és érdekek védelme, saját múködési adatok, egyes intézkedések hatása, stb.).

Az egyes tudástípusok azonosítására ugyancsak a fenti szerzőpáros ( Traunmüller-Wimmer, 2003a:143) dolgozott ki egy háromrétegú rendszerezô modellt, amelynek felsô, fogalmi rétege tartalmazza a három alapvetố tudástípust (folyamati, környezeti és tárgyi tudás), alsó rétege pedig a különböző tudáshordozókat veszi számba (információs rendszerek, az emberek tacit tudása; tárgyiasult absztrakt tudáselemek). A kettô között húzódik az ún. interakciós réteg, ahol a tudástípusok és megjelenési formáik kapcsolatba kerülnek egymással. Ezeknek a kapcsolatoknak a modellezésével tulajdonképpen valamennyi tevékenység és szolgáltatás lefedhető (2. táblázat).

2. táblázat

A tudástípusok azonosításának modellje

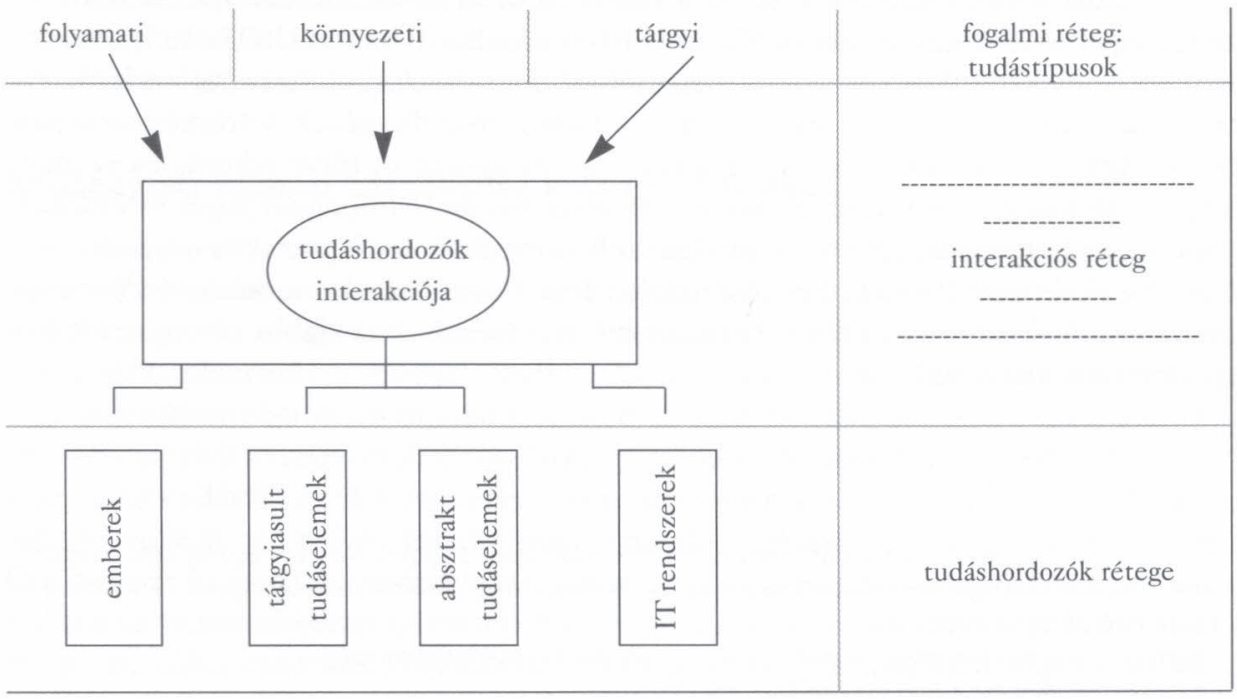


A tudástípusok és a tudáshordozók feltérképezését követi annak a felmérése, hogy miként használható fel a már létező tudás, hogyan termelhető új tudás, és miként biztosítható, hogy a rendelkezésre álló tudás folyamatosan hasznosítódjék. Mindehhez elemezni, majd osztályozni kell a közigazgatási környezetet, az intézményrendszert, a szolgáltatásokat és a munkafolyamatokat a tudásközpontú, illetve a tudástól független múködés szempontjából is. Lenihan (Lenihan, 2003:166) szerint a közigazgatási információs forrásokat és tudástárakat az állampolgári érdekek és prioritások szerint kell újraszervezni, szakítva a hagyományos keretekkel.

Az elemzések eredményei alapján történhet az általános mintának is tekinthe-


sa, ami azután útmutatóul szolgálhat az egyes intézmények saját tudásmenedzsmentpolitikájának és gyakorlatának megvalósításához is. A keretrendszernek az a legfontosabb szerepe, hogy egységes nyelvezetet teremtsen a tudásmenedzsmenttel kapcsolatos terminológia és az erre vonatkozó elméletek zúrzavaros világában, megkönnyítve a tudásmenedzsment fejlesztésére irányuló programban résztvevő valamennyi szereplő (a vezetôk, a végfelhasználók, a program kivitelezói, a beszállítók és a külsố szakértốk) munkájának és kommunikációs bázisának összehangolását. Egy ilyen dokumentum segítségével formalizálható a program tervezése és annak egész menete, optimalizálva a döntéshozatali folyamatokat is. A legfontosabb feladatok és folyamatok elôzetes végiggondolásával és felsorolásával minimálisra csökkenthetốk a hibák, és az egyes szervezeti egységek is biztonságosabban kezdhetnek bele a tudásmenedzsment fejlesztésére irányuló saját programjaikba, úgy, hogy azok beilleszkedjenek a központi tervek végrehajtásának menetébe. A keretrendszer nem helyettesíti, hanem csak kiegészíti és segíti a tudásmenedzsment kiépítését.

A közigazgatás bonyolult szervezeti felépítése és tevékenységi köre szükségessé teszi, hogy komoly szervezeti elemzô és tervezô munka előzzön meg minden gyakorlati lépést. A tudásmenedzsmenttel kapcsolatos szerteágazó feladatok és tevékenységek rendszerezésére Wiig (Wiig, 2000:5) az alapvető funkciókon alapuló felosztást javasol (3. táblázat).

- Irányítási funkciók: a tudással kapcsolatos tevékenységek nyomonkövetése és elősegítése.

- Személyzeti funkciók: a tudással kapcsolatos infrastruktúra és a személyi feltételek kialakítása, támogatása és naprakészen tartása.

- Múködési funkciók: a tudásvagyon létrehozása, megújítása, továbbépítése, rendszerezése és felhasználása.

- A „tudásban” rejlô lehetôségek kiaknázása: a tudásvagyon hatékony szétsugárzása és alkalmazása a termékekben, a szolgáltatásokban, a szabványokban és a technológiában, valamint egyéb rendszerekben és folyamatokban is.

\footnotetext{
${ }^{6}$ A leggyakrabban idézett keretrendszerek: Knowledge Management - A Framework for Succeeding in the Knowledge Era, Standards Australia, 2001 (http://www.knowledge.standards.com.au/); American Productivity \& Quality Center KM Framework (http://www.apqc.com); Global Knowledge Economic Council (http://www.gkec.org).
} 
3. táblázat

Példák a tudásmenedzsment tevékenységekre a négy tárgyalt területen (Wiig, 2000:6)

A „tudásban” rejlő lehetôségek maximális kiaknázása egy adott területen

\begin{tabular}{|c|c|c|c|}
\hline $\begin{array}{l}\text { Irányítási } \\
\text { funkciók }\end{array}$ & $\begin{array}{l}\text { Személyzeti } \\
\text { funkciók }\end{array}$ & $\begin{array}{l}\text { Múködési } \\
\text { funkciók }\end{array}$ & $\begin{array}{c}\text { A tudásban rejlő } \\
\text { lehetôségek kiaknázása }\end{array}$ \\
\hline $\begin{array}{c}\text { A tudással kapcsolatos } \\
\text { tevékenységek monitor- } \\
\text { ingja és elősegítése }\end{array}$ & $\begin{array}{c}\text { Tudás infrastruktúra ki- } \\
\text { alakítása és naprakészen } \\
\text { tartása }\end{array}$ & $\begin{array}{c}\text { A tudásvagyon létrehozá- } \\
\text { sa, megújítása, építése és } \\
\text { rendszerezése }\end{array}$ & $\begin{array}{c}\text { A tudásvagyon hatékony } \\
\text { szétsugárzása és alkalma- } \\
\text { zása }\end{array}$ \\
\hline $\begin{array}{c}\text { - az érintett terület tu- } \\
\text { dásvilágának fel-és letér } \\
\text { képezése }\end{array}$ & $\begin{array}{c}\text { - alap, szakmai és felsốfo- } \\
\text { kú oktatási intézmények } \\
\text { biztosítása }\end{array}$ & $\begin{array}{c}\text { - magas színvonalú okta- } \\
\text { tás és képzés a lakosság } \\
\text { számára }\end{array}$ & $\begin{array}{c}\text { - a tudásvagyon elveszí- } \\
\text { tésének, eltékozlásának } \\
\text { megelốzése }\end{array}$ \\
\hline $\begin{array}{l}\text { - a nemzeti tudásstraté- } \\
\text { gia és a szükséges szab- } \\
\text { ványok elkészítése }\end{array}$ & $\begin{array}{c}\text { - tudáscserén alapuló há- } \\
\text { lózatok kiépítése }\end{array}$ & $\begin{array}{l}\text { - könyvtárak, automati- } \\
\text { kus tudástárak fejlesztése }\end{array}$ & $\begin{array}{l}\text { - együttmúködések és } \\
\text { egyéb tudásmegosztó le- } \\
\text { hetôségek támogatása }\end{array}$ \\
\hline $\begin{array}{l}\text { - a tudással kapcsolatos } \\
\text { tevékenységek finanszí- } \\
\text { rozása és engedélyezése }\end{array}$ & $\begin{array}{c}\text { - a tanárok-, és oktatók } \\
\text { képzése }\end{array}$ & $\begin{array}{c}\text { - a felsőoktatási és ipari } \\
\text { K+F együttmûködés } \\
\text { szorgalmazása, támogatása }\end{array}$ & $\begin{array}{l}\text { - tudásalapú termékek és } \\
\text { szolgáltatások exportálása }\end{array}$ \\
\hline $\begin{array}{c}\text { - a tudás létrehozását, } \\
\text { megosztását, és használa } \\
\text { tát serkentô környezet } \\
\text { támogatása }\end{array}$ & - ipari parkok létesítése & $\begin{array}{c}\text { - az alapvetô ismeretek } \\
\text { és tudás szintjének eme- } \\
\text { lése és az ifjúság felké- } \\
\text { szítése a jövôre }\end{array}$ & $\begin{array}{c}\text { - szakképzett munkaerô } \\
\text { alkalmazása }\end{array}$ \\
\hline $\begin{array}{c}\text { - a tudással kapcsolatos } \\
\text { tevékenységek monitor- } \\
\text { ingja }\end{array}$ & $\begin{array}{c}\text { - alap- és alkalmazott ku- } \\
\text { tatási lehetőségek bizto- } \\
\text { sítása }\end{array}$ & $\begin{array}{l}\text { - az egyes iparágak közöt- } \\
\text { ti kutatások és fejleszté- } \\
\text { sek támogatása }\end{array}$ & $\begin{array}{l}\text { - magasan képzett mun- } \\
\text { kaerô biztosítása a mun- } \\
\text { kaerốpiac igényeinek ki- } \\
\text { elégítésére }\end{array}$ \\
\hline
\end{tabular}

Wiig a tudásmenedzsment valamennyi nagy feladatkörét ebben a négyes felosztásban tárgyalja, legyen szó a közigazgatási szolgáltatások megtervezéséről, a köztisztviselốk képzésérôl, a partnerek felkészítésérôl, az intellektuális tốke építésérôl a közigazgatásban, vagy a tudásmenedzsment gyakorlatának széleskörú elterjesztésérôl. Ô is hangsúlyozza (Wiig, 2000:18) a közigazgatási tudásmenedzsment tervezésének és kivitelezésének átfogó jellegét (közös megértés és jövőkép, tudástérkép, megvalósíthatósági elemzések, tudásstratégia, erőforrások, irányítás). Ennek alapvetô feltétele az együttmúködést, az adatcserét, a kommunikációt és a szolgáltatások fejlesztését lehetôvé tevô és koordináló szabályozási környezet megteremtése a szükséges normák, szabványok és technológiai architektúrák kidolgozásával. Egyrészt gondoskodni kell az egységes és kompatibilis technológiáról, másrészt egységesíteni kell a közigazgatási folyamatokkal és elképzelésekkel kapcsolatos nézeteket és a terminológiát is. 
A szabályozási környezet kialakítása mellett a hagyományos és e-kormányzati szolgáltatások (front-office folyamatok) tervezése, kidolgozása és múködtetése is központi koordinációt igényel. Az eEurope 2005 program alapgondolatai közé tartozik a tudásalapú gazdaság támogatása, továbbá a nyitottság, valamint az információk, a tudás és a tapasztalatok megosztása Európa- és világszerte. A tudásmegosztás, a közösen kezelt és használt adatok, az együttmúködés és az osztott rendszerek létrehozása jobb, intenzívebb, rugalmasabb és olcsóbb szolgáltatást biztosító közigazgatást eredményez.

Mint már korábban jeleztük, a közigazgatási reform és az azt támogató e-kormányzati törekvések központi feladata az állampolgároknak és az üzleti szférának elektronikus úton nyújtott, integrált, „egyablakos” szolgáltatások fejlesztése és azok minôségének javítása. A hagyományosan hierarchikus berendezkedésű közigazgatási rendszerek intézményei mindeddig nem az állampolgárok és a privát szféra igényei felől közelítették meg szolgáltatási funkciójukat, hanem saját intézményi kereteik és munkafolyamaik alapján. Az üzleti és kereskedelmi életben a webalapú rendszerekhez és az Interneten keresztül lebonyolított tranzakciókhoz szokott gazdasági szereplôk a lakosságot is magukkal vonva - egyre határozottabban elvárják a kormánytól és a közigazgatástól, hogy ezeken a területeken is hasonló színvonalú és metódusú szolgáltatásokat kapjanak. A szolgáltatásokhoz és az adatokhoz való könnyebb, gyorsabb és jobb hozzáférés, valamint az online ügyintézés lehetôségének megteremtése azonban nem merülhet ki csupán a kormányzati és a közigazgatási munka automatizálásában. A jelenleg még alapvetôen hierarchikusan szervezett intézmények tevékenysége egyre inkább lapos szerkezeti struktúrát és horizontális együttmúködést fog igényelni, hiszen a szolgáltatások nagy része többcsatornás ügyfélkezelést kíván meg. Mindez a technológia, a rendszerek, a szakértelem és a munkamódszerek összehangolását és megosztását igényli. A kormányzati munka állami, megyei és helyi önkormányzati szintjei gyakorta összeolvadnak az állampolgárok szemében, s így az igényeket kielégítő szolgáltatások megvalósítása attól is függ, hogy miként lehet ezeket a szinteket a külvilág számára is láthatóan integrálni. Az „egykapus” portálok kialakítása mögött olyan szolgáltatási szemlélet formálódik, ami az állampolgárt valamennyi adminisztrációs igényével együtt oszthatatlan egységnek tekinti. Ennek jegyében a mindennapi élet valamennyi eseményével és tevékenységével kapcsolatos ügyintézés (születés, házasság, építkezés, vállalkozás, stb.) egy helyen és a felhasználó számára egyszerú módon történik (life-event portals) (Leben-Bohanec, 2003:25). A szolgáltatói oldalon mindez a kétoldalú kommunikációt biztosító portál mögötti, teljesen integrált és a szervezeti tagoltságot feledtető múködési és szolgáltatási feltételeket igényel.

Az Európai Unióban számtalan kutatási és fejlesztési program bizonyítja, hogy a tudásmenedzsment ezen a területen is jelentős támogatást jelenthet (a közigazgatási munka minőségének javítása, az intézményközi együttmúködés elvi és technikai feltételeinek biztosítása, adat- és tudás-reprezentáció, a közigazgatási tudásmenedzsment-rendszerekkel szemben megfogalmazott elvárások teljesítése, a tudásmenedzsment eszközeinek a közigazgatás szolgálatába állítása). Példaként említhető a páneurópai közigazgatási szolgáltatások fejlesztése (Adam-Werth-Zangl, 2003:1; Tarabanis-Peristeras, 2003:37), ami többek között a szabad munkaeróáramlás által a tagországok közigazgatási rendszereivel szemben támasztott kihívásokra keresi a megoldást. Az EU-n belüli közigazgatási rendszerek heterogén jogi és szerkezeti háttere kizárja az általános központosítás és harmonizáció lehetőségét. A megoldást olyan szab- 
ványok kidolgozása és alkalmazása jelentheti, amelyek révén átláthatóvá válnak az adminisztrációs folyamatok, és így növelhető az együttmúködés.

2004 elején zárult le a SmartGov elnevezésű, kétéves nemzetközi program, amelynek célja egy olyan egységes, tudásalapú kormányzati platform kialakítása volt, ami a szükséges eszközök biztosításával lehetôvé teszi elektronikus közigazgatási szolgáltatások kialakítását és múködtetését. A program záródokumentuma szerint (SmartGov, 2004:5) elkészült az elektronikus szolgáltatások felépítéséhez szükséges tranzakciós elemeket és tudásegységeket tartalmazó tudástár, az e-kormányzati szolgáltatások fejlesztéséhez szükséges keretrendszer, és az e-kormányzati szolgáltatások ontológiája.

\section{A közigazgatási intézmények belső (back-office) működési folyamatainak átformálása}

Az intézményi szintű belső működési reform során visszaköszönnek a központi feladatok, és e két területet természetesen nem lehet és nem is szabad élesen elválasztani egymástól. A közigazgatási intézményekben az egységes és múködőképes rendszer kialakítása érdekében a tudásmenedzsmenttel összefüggő valamennyi tevékenységet hozzá kell igazítani a központi kormányzati elgondolásokhoz. Ez az a terület, ahol a közszféra a legtöbbet profitálhat a privát szektornak a tudásmenedzsment terén szerzett tapasztalataiból, illetve ahol forgatókönyvszerú megoldási javaslatok állnak rendelkezésre. Igyekszünk azonban hangsúlyozni, hogy sem a szakirodalom, sem a tudásmenedzsment gyakorlata nem kínál kész megoldásokat egyetlen szervezet számára sem. Adott viszont a szemlélet, illetve az eszközrendszer és az alkalmazható eljárások gazdag tárháza, és rendelkezésre állnak az eddig felhalmozott tapasztalatok és kutatási eredmények.

A szervezeti tudásmenedzsment megvalósításának folyamatát korszakolással, szintezéssel szokás szemléltetni. A $K P M G$ (2000) tanácsadó cég ötlépcsős értékelő rendszert dolgozott ki erre a célra (Knowledge Journey). A tudásalapú múködés vizsgálatai alapján a kaotikus állapottól a tudás jelentőségét felismerô, majd központi célként kezelő szinten át, a tudásvagyon tudatos és szisztematikus menedzseléséig és végül a tudásközpontú szervezetek megvalósításáig visz az út. A tudásmenedzsment kiépítése során elvégzendô fốbb feladatokat az $A P Q C$ modellje szintén öt lépésben határozza meg.

- Projektindítás: a tudásmenedzsment mibenlétének és céljainak megismertetése a szervezettel, és a lehetséges kiemelt támogatók, együttmúködők azonosítása.

- Stratégia kidolgozása: a tudásmenedzsment-program felvázolása és ütemezése, felelős részleg és felelős személyek kijelölése, kísérleti (pilot) program megtervezése és a finanszírozás feltételeinek biztosítása.

\footnotetext{
A kutatásban görög, német, brit és spanyol egyetemek és intézmények múködtek közre. A projekt honlapja: http://www.smartgov-project.org/
} 
- A tudásmenedzsment-program kidolgozása és beindítása, múködtetési, mérési és értékelési módszerek kidolgozása, kísérleti programok segítségével.

- A projekt kiterjesztése és folyamatos támogatása; a stratégiai, pénzügyi és kulturális feltételek biztosítása.

- A tudásmenedzsment intézményesítése: a tudásmenedzsment beágyazása a szervezet struktúrájába, múködésébe, költségvetésébe és szervezeti kultúrájába.

\section{Tudásmenedzsment-stratégiák}

Az egyes szervezetek szintjén is szükség van a tudásmenedzsment-stratégia kidolgozására. Az eddigi tapasztalatok alapján célravezetô a szervezet egészét átfogó tervezés és a kis lépésekben történő megvalósítás, azaz kísérleti programok indítása. A szervezeti tudásmenedzsment-stratégia megfogalmazásánál célszerú figyelembe venni az általános tudásmenedzsment eddig kialakult alapvetố stratégiai irányzatait (Hansen et al., 1999:107) és azok alkalmazásának széleskörú tapasztalatait. Hagyományosan kétféle megközelítés alakult ki: a rendszerező stratégia (codification) és a kapcsolati stratégia (personalization). A rendszerezố stratégia elsôsorban a dokumentált (explicit) tudásra koncentrál, s ennek menedzselésével törekszik a múködés hatékonyságának növelésére. A tudást olyan értéknek tekinti, ami folyamatos pénzügyi beruházást igényel. A tudásmenedzsment középpontjában leginkább a módszerek fejlesztése és egy átfogó elektronikus dokumentumkezelő rendszer kiépítése áll. Az adott szervezet információs folyamatainak elemzése után meghatározza a szervezet múködésére jellemző tudáselemek körét, és olyan számítógépes hálózat és rendszer kiépítésére törekszik, ami elôsegíti ezeknek a tudáselemeknek a rendszerezését, visszakereshetőségét, megosztását és többszöri felhasználását. Ezzel szemben a kapcsolati stratégia inkább az emberekre, azok személyes tudására és kapcsolatrendszerére koncentrál. A technológia fejlesztése nem annyira a dokumentumkezelésre, mint inkább a kommunikáció támogatására irányul. A cél olyan szervezeti kultúra kialakítása, ahol az alkalmazottak személyes érintkezésén keresztül szabadon áramolhat az információ és a tudás. Míg a kodifikáló szemlélet a tudásbázis használatát, addig a kapcsolati stratégia a közvetlen tudásmegosztást szorgalmazza. Mind a két megközelítés tartalmazza a másik felfogás bizonyos elemeit is, de az egyik esetben főként az emberek és a dokumentumok, míg a másik esetben csak az emberek közötti kapcsolatokra kerül a hangsúly. Az elektronikus kormányzat, de a hagyományos közigazgatási munka támogatásánál is mindkét stratégia alkalmazásának van létjogosultsága, attól függően, hogy melyik cselekvési terület tudásrendszerérôl van szó (pl. a törvényhozási és jogalkotási, továbbá az országos, regionális és szakterületi stratégiák kidolgozásánál inkább a kapcsolati, míg az adatnyilvántartás, az ügyintézés és az egészségügy területén inkább a kodifikáló stratégia alkalmazása bizonyul célszerûnek).

A fentiektől bizonyos mértékig eltérô szemléletként említhető a környezeti (context-based) stratégia, ami az ún. produktív tudásra és a szervezet változási képességének fejlesztésére koncentrál. Elsősorban a szervezeti struktúrában azonos szinten elhelyezkedố vezetôk tudáscseréjét, a hozzáadott értékkel növelt tudást jutalmazza, és az igények oldaláról, a pull technikák alkalmazásával közelíti meg és építi fel a tudásrendszert. (A rendszerezô stratégiát inkább a push technikák alkalmazása, 
míg a kapcsolati stratégiát a két módszer vegyítése jellemzi.)

A stratégia megvalósítása tulajdonképpen nem más, mint a szervezet tudásmenedzsment- rendszerének kiépítése, ami a privát szektor területén már bevált metodológia alapján az alábbi fó alkotórészekből ${ }^{8}$ áll: emberek, folyamatok, vezetés és technológia (4. táblázat).

4. táblázat

\section{A tudásmenedzsment- rendszer fố alkotórészei}

\begin{tabular}{|c|c|c|c|c|}
\hline & Emberek & Folyamatok & Vezetés & Technológia \\
\hline$\frac{\frac{1}{0}}{\frac{0}{\pi}}$ & $\begin{array}{l}\text { A TM beépül a } \\
\text { szervezeti kultúrá- } \\
\text { ba, a tudás és a tel- } \\
\text { jesítmény szorosan } \\
\text { összefonódik egy- } \\
\text { mással. }\end{array}$ & $\begin{array}{l}\text { A TM a munkafolya- } \\
\text { matok szerves részét } \\
\text { képezi, nem önálló } \\
\text { célként vagy önálló } \\
\text { tevékenységként je- } \\
\text { lenik meg. }\end{array}$ & $\begin{array}{l}\text { A TM elvei jelen } \\
\text { vannak a szervezet } \\
\text { stratégiai tervében, } \\
\text { és ezeket a felsô ve- } \\
\text { zetés támogatja. }\end{array}$ & $\begin{array}{l}\text { A szervezet jól át- } \\
\text { gondolt és megter- } \\
\text { vezett információs } \\
\text { rendszere megfelelő } \\
\text { módon múködik és } \\
\text { lefedi az emberek, } \\
\text { folyamatok és ese- } \\
\text { mények teljes háló- } \\
\text { zatát. }\end{array}$ \\
\hline $\bar{v}$ & $\begin{array}{l}\text { Olyan új viselkedési } \\
\text { kultúra meghonosí- } \\
\text { tása, ami lehetôvé } \\
\text { teszi a tudásterme- } \\
\text { lésen, a tudás meg- } \\
\text { osztásán és újrafel- } \\
\text { használásán alapuló } \\
\text { szervezeti kultúra } \\
\text { kialakítását. }\end{array}$ & $\begin{array}{l}\text { Az emberek és a } \\
\text { szervezet tevékeny- } \\
\text { ségeit koordináló } \\
\text { struktúra, ill. olyan } \\
\text { rendszerek kiépíté- } \\
\text { se, amelyek révén } \\
\text { megvalósul a tudás } \\
\text { megszerzése, meg- } \\
\text { osztása és létrehozá- } \\
\text { sa. }\end{array}$ & $\begin{array}{l}\text { Egyértelmü és kö- } \\
\text { vetkezetes stratégia } \\
\text { létrehozása. }\end{array}$ & $\begin{array}{l}\text { A tudásmegosztáson } \\
\text { alapuló környezet } \\
\text { megvalósítása, illet- } \\
\text { ve támogatása. }\end{array}$ \\
\hline 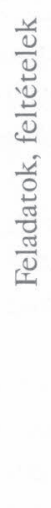 & $\begin{array}{l}\text { a tudásmegosztás } \\
\text { ösztönző rendszer } \\
\text { kiépítése, az ered- } \\
\text { mények és a sikerek } \\
\text { folyamatos publiká- } \\
\text { lása, hangsúly- } \\
\text { ozása,a kölcsönös } \\
\text { bizallomra épülő } \\
\text { szervezeti kultúra } \\
\text { megteremtése,a } \\
\text { gyakorlat-közössé- } \\
\text { gek támogatása. }\end{array}$ & $\begin{array}{l}\text { a tudás összegyújté- } \\
\text { se, a tudásvagyon } \\
\text { felmérése és } \\
\text { értékelése,a tudás } \\
\text { „terítése” (szerkesz- } \\
\text { tés, tárolás, rendsze- } \\
\text { rezés, megosztás),a } \\
\text { tudásbázis folyama- } \\
\text { tos fejlesztése,a tu- } \\
\text { dás- és adatvédelem } \\
\text { biztosítása,új tudás } \\
\text { létrehozása. }\end{array}$ & $\begin{array}{l}\text { a vezetés elkötele- } \\
\text { zettsége a TM } \\
\text { támogatására,a TM- } \\
\text { et koordináló és irá- } \\
\text { nyító szervezeti } \\
\text { egység létrehozása, } \\
\text { tudásigazgató } \\
\text { (Chief Knowledge } \\
\text { Officer) kinevezése }\end{array}$ & $\begin{array}{l}\text { számítástechnikai } \\
\text { eszközök, szoftve- } \\
\text { rek és hálózati inf- } \\
\text { rastruktúra, szerve- } \\
\text { zeti intranet,tudás- } \\
\text { portál, a folyamatok } \\
\text { automatizálása, ha- } \\
\text { tékony, gyors, egy- } \\
\text { séges hozzáférést } \\
\text { biztosító adattároló } \\
\text { rendszer, a kommu- } \\
\text { nikáció támogatása. }\end{array}$ \\
\hline
\end{tabular}

Forrás: $K P M G$ alapján TM=tudásmenedzsment 
A tudásmenedzsment támogatásának fó eszköze a tudáskezelő vagy tudásmenedzsment rendszer (knowledge management system, KMS). A Lotus/IBM felfogása szerint a tudásmenedzsment rendszert alkotó technológiai eszközök öt nagy csoportba sorolhatók:

- Az üzleti intelligenciát támogató eszközök: a stratégiai alapinformációk tudássá konvertálása (adattárházak, adatbányászat, OLAP, stb.);

- az együttmúködést támogató eszközök: csoportmunka, spontán munkaközösségek, külsố és belsố kommunikáció (groupware, e-mail, video-konferencia);

- a tudástranszfert támogató eszközök: a megfelelő tudás eljuttatása a megfelelő személyekhez (számítógépes oktatás, e-learning);

- tudásfeltáró rendszerek: a strukturálatlan adatok feltárására, rendszerezésére és visszakeresésére alkalmas keresô, navigációs, dokumentumkezelô és adatelemzô eszközök;

• a szakértốk lokalizálására szolgáló rendszerek: „ki mit tud”-rendszer.

Mindezeket az eszközöket az információs portálok vagy tudásportálok integrálják. Az ilyen portálok kialakításához felhasznált technológia egységes felületet szolgáltat a felhasználók számára és lehetôvé teszi, hogy egyrészt testre szabott információt közvetíthessünk rajta az egyes felhasználók, a munkafolyamatok és a szervezet igényei szerint, másrészt a felhasználók könnyen definiálhassák információs igényeiket és kezelhessék az információs bázisokat.

A technológia megalapozza és támogatja a tudásmenedzsment-rendszer lelkét jelentố tartalom biztosítását, valamint a bonyolult összetételú - esetünkben e-kormányzati - közösség kiépítését. Míg a tartalom alatt a meglévô és az ezután elérendő információforrások tartalmának számbavételét és a jövőben ezekre alapozandó, rugalmas kodifikáló és visszakeresố rendszer kialakítását értjük, addig a közösségépítés a potenciális szereplốk számbavételét, azok szerepének és szükségleteinek meghatározását, valamint funkcionális és jogosultság szerinti csoportosítását jelenti. Az intézményi kereteken túlra is kiterjedő, szakmai szempontok alapján kialakítandó virtuális közösségek (communities of practice) - szellemi tôkéjük rendelkezésre bocsátásával az indulási fázistól kezdve katalizátorként funkcionálhatnak.

Az egyes intézményeken belüli, valamint az intézmények közötti kommunikációt és a tudásmegosztást ösztönzô technológiai háttér hatékonyan támogatja a tudásmenedzsment szemlélet elterjedésén és alkalmazásán alapuló szervezeti kultúra kialakítását is. A tudásmenedzsment szakirodalmában gyakran hangoztatott vélemény, hogy a megfelelő, elfogadó és támogató környezet kialakítása jelenti a legnagyobb nehézséget. Általánosságban elmondható, hogy a különbözố vállalatok, szervezetek és intézmények hagyományos szervezeti kultúrájában pontosan a tudásmegosztás ellentettjét, a tudás megtartásán és visszatartásán alapuló versenyszellemet fedezhetjük fel. Az egyének érvényesülése, bizonyos értelemben véve, hatalmi pozíciója és munkahelyi biztonsága azon alapul(t), hogy milyen mértékben birtokolnak (vagy birtokol-

\footnotetext{
${ }^{8}$ A George Washington University tudásmenedzsment doktori programjában résztvevố kutatók által kidolgozott modell szerint a négy alapvető összetevő a vezetés, a szervezet, a technológia és a tanulás. Az egyes elemek kifejtésénél azonban azt találjuk, hogy a két-két eltérổ elemet jellemzố elvek és funkciók erôs hasonlóságot mutatnak, így az eltérés inkább terminológiai jellegü.
} 
tak) a szervezet számára nélkülözhetetlen tudást vagy információt. Fokozottan igaz ez a közigazgatásra. Traunmüller és Wimmer szerint (Traunmüller-Wimmer, 2003a:140) a kormányzatok és a közigazgatás gondolkodásmódja még nem érett a tudásmenedzsment alkalmazására. A legtöbb köztisztviselố nem tartja magát tudásmunkásnak, nincs tudatában az adott intézményben meglevő tudás jelentőségének, vagy egyszerúen csak nem tulajdonít annak jelentôséget. Sveiby (Sveiby, 2002) egyik felmérésében azt vizsgálta, hogy a tudásmegosztást támogató, tudásbarát környezet milyen hatással van a munkavégzés általános minőségére, illetve a kitúzött szervezeti célok elérésére. A felmérés eredménye szerint a közszférában jóval alacsonyabb az együttmúködésre való hajlam, mint a privát szektorban. A közigazgatási munka a rugalmasság, a piacorientáltság, a profitra való törekvés vagy a finanszírozás tekintetében természetesen nem hasonlítható össze a privát szféra vállalataival. A közszférában nincs hagyományos értelemben vett konkurencia, csak állampolgári elvárások vannak. A fố kihívás a hatékonyság növelése; a munkatársak szeme előtt csak az elhivatottság, a megfelelés és a magasabb színvonalú munkavégzés iránti vágy, vagy a közjó emelésének feladata lebeghet. Tovább nehezíti a helyzetet, hogy az utóbbi idők általánosan jellemző létszámcsökkentő politikájával a kormányzatok jelentôs tudásvagyontól estek el. A humán erôforrásokkal való gazdálkodást jelenleg gátolja a közigazgatásra hagyományosan jellemzô igen magas fluktuáció, valamint a kormányzati szférában való elhelyezkedés viszonylagos népszerütlensége, elsősorban a fiatal, magasan kvalifikált munkavállalók körében. Majdnem minden országban gondot jelent az államigazgatásban tapasztalható elöregedés, és ebból fakadóan a szakember-utánpótlás hiánya. Eddig kevéssé került a középpontba a munkaerố által képviselt szellemi tôke tudatos védelme és az azzal történő gazdálkodás. Ilyen környezetben teljességgel lehetetlen a tudásmegosztás hatékonyságáról beszélni. A tudásmenedzsmenthez nélkülözhetetlen alapvetố szemléleti váltáshoz átgondolt, felülrôl koordinált és támogatott intézkedések szükségesek. A szervezeti változásokat, a munkafolyamatokat, a finanszírozási, javadalmazási és jutalmazási rendszert, a belső és külső kommunikáció formáit és eszközeit úgy kell végiggondolni és megvalósítani, hogy az alkalmazottak még rutinfeladataik elvégzése közben is rá legyenek szorítva a tudásmegosztás szellemében történố munkavégzésre.

\section{A tudásmenedzsment „állampolgár formáló” hatása}

Az információs társadalomnak a lakosság aktivizálására és képzésére irányuló célkitûzései szintén a tudás megosztását szorgalmazó, tudásközpontú szemlélet elốtérbe helyezését igénylik. Az eEurope 2005 stratégia - a részvételen alapuló demokrácia (participatory democracy) szellemében - kiemelten támogatja az olyan kormányzati struktúra és légkör kialakítását, ahol a lakosság az eddiginél hatékonyabban részesévé válhat a mindennapi életét meghatározó törvényalkotási és végrehajtási folyamatoknak. Az elektronikus szavazás, a közösségi hozzáférést biztosító hálózati pontok kialakítása, a szegényes erőforrásokkal rendelkező kistelepülések és térségek felzárkóztatása, az Interneten keresztül történő véleménynyilvánítás lehetőségeinek megteremtése és a civil szervezetek támogatása mind azt a célt szolgálja, hogy az állampolgárok érintettebbek és érdekeltebbek legyenek a demokráciában és a közösségi döntéshozatali folyamatokban való aktív részvételben. Az állam, amennyiben tisztá- 
ban van szerepével, komolyan veszi küldetését és meg akar felelni a szolgáltató állam szerepköréből adódó kihívásoknak, csak profitálhat az állampolgári részvételből és visszajelzésekbôl. Az állampolgári részvételt és öntudatot képzéssel, tájékoztatással és a megfelelő infrastruktúra biztosításával lehet és kell növelni.

\section{A kormányzatoknál megualósult tudásmenedzsment egy nemzet- közi felmérés tükrében}

Az eddigi egyetlen átfogónak mondható és nyilvános nemzetközi felmérést a tudásmenedzsmenttel kapcsolatos nézetekrôl és annak gyakorlatáról a kormányzati munkában és a közszférában az $O E C D$ végezte 2002 januárjában. A felmérés ${ }^{9}$ célja az volt, hogy feltérképezze és dokumentálja a tudásmenedzsment megjelenése által előidézett változásokat a kormányzati munka különböző szintjein és területein. A felmérés megállapításai alapján a tudásmenedzsment nem csupán elôkelő helyen szerepel az $O E C D$ tagországok központi kormányzatainak menedzsmentjében, ${ }^{10}$ de több országban az elkövetkező esztendôkben a menedzsment előtt álló öt legfontosabb feladat között tartják számon. Egyre inkább terjed a tudásmegosztó eszközök használata, a legtöbb helyen már adott az e-kormányzat alapvető feladatainak ellátásához szükséges technológia. A felmérés eredményei is megerősítették, hogy a közszféra is nyit a tudásmenedzsment újszerű elveinek, módszereinek és eszközeinek alkalmazása felé (létrejönnek a tudásmenedzsmenttel foglalkozó központi szervezeti egységek és szakmai közösségek, fokozottabb együttmúködés alakul ki külső szervezetekkel), valamint olyan kulturális változások figyelhetôk meg, mint például a spontán tudásmegosztás gyakorlata a karrierépítéshez korábban nélkülözhetetlennek tartott tudásmegtartás magatartásával szemben, vagy a vezetôi feladatok kiszélesedése. Jóllehet láthatóan növekedett a nyitottság és átláthatóság, továbbá az információs és kommunikációs technológiák használatba vételével általában javult a hatékonyság és az eredményesség, számos helyen még nem történt meg a tudásmenedzsment által szorgalmazott szerkezeti változás. Egyes szervezetek még mindig gyakran alábecsülik a humán tényezók szerepét a tudásmenedzsmentben, a tudásmegosztás továbbra is informális és korlátozott mértékű. Továbbra is jelentôs az alkalmazottak ellenállása, a nem dokumentált ismeretek feltárása nehézkes. A kormányintézmények túlnyomó részében azonban már a hivatalnokok rendelkezésére állnak az e-kormányzat megvalósításához szükséges alapvetô technológiai eszközök. A felhasználók felé irányuló külső tu-

\footnotetext{
${ }^{9}$ A kérdőívekre 20 ország 132 kormányzati szerve vagy intézménye küldte el a választ. A válaszok nagy száma és jó kidolgozottsága lehetôvé teszi, hogy a felmérés eredményeit felhasználva mélyebb elemzés is készüljön a tudásmenedzsment helyzetérôl a kormányzati szférában.

${ }^{10} \mathrm{Az}$ OECD által végzett értékelés szerint az élcsoportban található Franciaország, Svédország, Finnország, Kanada és Izland. Az OECD-átlag alatt maradó országok Lengyelország, Belgium és Portugália. Hazánk a középmezôny egyik sereghajtójaként az alábbi országokkal került egy csoportba: USA, Nagy-Britannia, Írország, Korea, Norvégia, Dánia, Szlovénia, Németország és Görögország. A profil szerinti megoszlást tekintve vezetố helyen találhatók a pénzügyi, igazságügyi és gazdasági, ipari szervezetek, a sor végén pedig a belügyi és államigazgatási intézmények állnak.
} 
dásmegosztás tekintetében négy szintet ${ }^{11}$ különböztethetünk meg. Az első, információs szintet a szolgáltatásokat ismertető honlap jelenti. A második szinten az interaktív módon kezelhetố információkat tartalmazó webkikötők már lehetôséget nyújtanak a felhasználóknak a hivatal adatbázisainak használatára. A harmadik szinten lehetőség nyílik ügyintézésre is, azaz a felhasználók biztonságos módon adatokat is vihetnek be a rendszerekbe, míg a fejlesztés végcélja az adatcserére, illetve adatmegosztásra alkalmas negyedik szint elérése, ahol a hivatal - a felhasználók beleegyezésével - a tárolt adatokat képes megosztani más kormányzati intézményekkel is. ${ }^{12}$

A pozitív példák és eredmények ellenére a felmérés értékelésének végsố kicsengése az, hogy a tudásmenedzsmentről a kormányzati szférában még elég ködös elképzelések élnek, és ezeket gyakorta nagy szakadék választja el a valóságtól.

A közigazgatás összetettsége, szövevényes szervezeti felépítése és sokszínú tevékenysége miatt gyakori annak a véleménynek a hangoztatása, hogy ebben a környezetben szinte lehetetlen a tudásmenedzsment sikeres alkalmazása. Meggyôzôdésünk azonban, hogy átgondolt, szisztematikus elemzés és tervezés után a privát szféra szervezeteihez hasonlóan a közigazgatásban is lehetséges a munka minőségének, hatékonyságának és feltételeinek nagymértékú jobbítása, s ezen keresztül mind a hivatalnokok, mind a lakosság általános közérzetének és elégedettségének javítása is.

\section{IRODALOM}

APQC's Road Map to Knowledge Management Results: Stages of Implementation ${ }^{\text {TM }}$ http://www.apqc.org/portal/apqc/site/generic?path=/site/km/apqc_roadmap.jhtml (utolsó elérés: 2004. 04. 25.)

Barquin, R. C., - Bennet, A., - Remez, S. G. (2001).: Knowledge Management. The Catalyst for Electronic Government, Vienna, Virginia : Management Concepts, Inc.

Bixler, C. (2002). KM: a source of practical solutions to emerging government needs, KMWorld, Sept. v11 i8 p18(2).

Barquin, R. G. -, Bennet, A. ,- Remez, S. G. (2001):. Building Knoweledge Management Environments for Electronic Government. Vienna, Virginia : Management Concepts, Inc.

\footnotetext{
${ }^{11}$ A felmérés az ausztráliai országos auditáló hivatal (Australian National Audit Office) által kifejlesztett modell szerint osztályozta a hivatalokat. Teljesen egybecseng ezzel a felosztási modellel az Európai Bizottság által javasolt e-kormányzati szolgáltatásokat osztályozó rendszer is, ahol szintén az információs, majd eleinte egyoldalú, késóbb kétoldalú interakciót biztosító, végül tranzakciókra lehetôséget nyújtó szintekkel találkozunk.

${ }^{12} \mathrm{Az}$ elsô szintet majdnem minden válaszadó túlhaladta. A megkérdezettek 95\%-a biztosítja az alábbi alapvetố szolgáltatásokat: az adminisztrációval kapcsolatos információkhoz való hozzáférés, aktuális események és információk, lehetôség az intézmény kiadványainak és jelentéseinek letöltésére (1. szint). Adminisztratív adatok, statisztikák, jelentkezési lapok és ûrlapok letöltése az esetek 77-85\%-ában volt lehetséges (2. szint), míg csak 50\%-ban nyílt mód az úrlapok kitöltésére elektronikus úton, és mindöszsze 5\%-ot tett ki az elektronikus fizetési lehetőségek biztosítása (3. szint).
} 
Conclusions from the Results of the Survey of Knowledge Managmenet Practices for Ministries/Departments/Agencies of Central Government in OECD Member Countries (2003). OECD Public Governance and Territorial Develpoment Directorat - Public Managemenet Committee. http://www.oecd.org/ (utolsó elérés: 2004.04.25.)

eEurope (2002). eEurope 2005 - an information Ssociety for all. European Commission. http://europa.eu.int/information_society/eeurope/news_library/documents/e europe2005/eeurope2005_en.pdf (utolsó elérés: 2004. 04. 25.)

Davenport, T. H. -, Prusak, L. (2001).: Tudásmenedzsment. Budapest, Kossuth K.

Géró Katalin (2004). Tudásmenedzsment a kormányzati munkában. Kutatási Jjelentés, 25, pp.: 61-82.

Hansen, M. -, Nohria, N. \&\& Tierney, T. (1999, March-April): What's your strategy for managing knowledge? Harvard Business Review, reprint 990206

Harman, G. -, Brelade, S. (2001).: Knowledge, E-Government and the Citizen. Knowledge Management Review, Jul/Aug, Vol. 4 Issue 3, p. 18

Klimkó G. (2001).: A szervezeti tudás feltérképezése, Ph.D. értekezés http://www.lib.bke.hu/phd/klimko_gabor.pdf (utolsó elérés: 2004.04.25.)

Közigazgatási Intézet (2002): Közigazgatási- szervezési és vezetési ismeretek. (2002). (közread. a) Magyar Közigazgatási Intézet., 210 p. http://www.mki.gov.hu/file/kszervvez.doc (utolsó elérés: 2004.04.24.)

KPMG Consulting (2000).: Knowledge Management Research Report 2000. http://www.kpmg.nl/ Docs/Knowledge Advisory_Services/KPMG\%20KM\%20Research\%20 Report\%202000.pdf (utolsó elérés: 2004.04.24.)

Lenihan, Donald (2003).: Information Sharing: Toward Collaborative Governance. Expanding Public Space for the Development of the Knowledge Society: Report of the Ad Hoc Expert Group Meeting on Knowledge Systems for Development, 4-5 September 2003, Department of Economic and Social Affairs, Division for Public Administration and Development Management, United Nations, New York, p. 166.

Malhotra, Y. (1998): Knowledge Management, Knowledge Organizations and Knowledge Workers: a View from the Front Lines (online), http://www.brint.com/interview/maeil.htm (utolsó elérés: 2004.04.25.).

Malhotra, Y. (1998): Tools@work: Deciphering the Knowledge Management Hype, The Journal for Quality and Participation; Cincinnati; Jul/Aug 1998, 21(4), pp. 58-60

Misra, D.C. -; Hariharan, Rama -; Khaneja, (2003): E-Knowledge Management Framework for Government Organiozsations. Manie. Information Systems Management, Spring, Vol. 20 Issue 2, p. 38

Nonaka, I. -, Takeuchi, H. (1995): The Knowledge-Creating Company - Hy - How Japanese Companies Create the Dynamics of Innovation. Oxford University Press, Inc., USA

Polányi Mihály (1994).: Személyes tudás. Úton egy posztkritikai filozófiához. Bp: Atlantisz

Saussois, J-M. (2003): Knowledge Management in Government: An Idea Whose Time Has Come. OECD - Learning Government Symposium, Paris, 3-4 February 2003. 
SmartGov (2004): A Governmental Knowledge-based Platform for Public Sector Online Services (Projekt Number: IST-2001-35399). Final Project Report http://www.smartgov-

project.org/index.php?category $=$ viewsummary\&langid $=$ eng\&dlFileDesc $=$ D13 (utolsó elérés: 2004.04.25.)

Sveiby, K. (1996-2001).: What is Knowledge Management?

http://www.sveiby.com/articles/KnowledgeManagement.html (utolsó elérés: 2004.04.25.)

Sveiby, K. (2000): Knowledge Management - The Viking Way http://www.sveiby.com/articles/vikings.htm\#three (utolsó elérés: 2004. 04. 25.)

Sveiby, K. (2002).: Collaborative Climate and Effectiveness of Knowledge Work - an Empirical Study. Journal of Knowledge Management, Vol. 6 No. 5 ,

Traunmüller, R. -, Wimmer, M. (2003a):. Knowledge Management for Government: Enhancing the Quality of Public Service. (Expert Background Paper),

Expanding Public Space for the Development of the Knowledge Society: Report of the Ad Hoc Expert Group Meeting on Knowledge Systems for Development, 4-5 September 2003, Department of Economic and Social Affairs, Division for Public Administration and Development Management, , New York, p. 128-163.

Traunmüller R. ,- Wimmer, M. (2003b): 2003. e-Government at a Decisive Moment: Sketching a Roadmap to Excellence. In: R. Traunmüller (Ed.), EGOV 2003, 2nd International Conference on e-Government, Springer Verlag, LNCS \# 2739, Heidelberg et al, Septembe, p. 1-14.

Wiig, K. M. (2000): Application of Knowledge Management in Public Administration. Proceedings of the International Symposium on Building Policy Coherence. Taipei, Taiwan: City of Taipei 